\title{
Analysis of Several Inflammatory Markers Expression in Obese Rats given Plectranthus amboinicus (Lour.) Spreng Ethanol Extract
}

\author{
Karnirius Harefa' ', Delmi Sulastri' ${ }^{1}$ Ellyza Nasrul', Syafruddin Ilyas',**
}

Karnirius Harefa', Delmi Sulastri1, Ellyza Nasrul', Syafruddin Ilyas ${ }^{2, *}$

'Study Programme of Biomedic, Faculty of Medicine, Universitas Andalas, Padang, INDONESIA.

${ }^{2}$ Department of Biology, Faculty of Mathematics and Natural

Sciences, Universitas Sumatera Utara, Medan, INDONESIA.

\section{Correspondence}

\section{Syafruddin Ilyas}

Department of Biology, Faculty

of Mathematics and Natural

Sciences, Universitas Sumatera Utara,

Medan, INDONESIA.

E-mail: syarifunddin6@usu.ac.id

\section{History}

- Submission Date: 23-10-2020;

- Review completed: 18-11-2020;

- Accepted Date: 23-11-2020;

DOI : 10.5530/pj.2021.13.24

Article Available online

http://www.phcogj.com/v13/i1

Copyright

(C) 2021 Phcogj.Com. This is an openaccess article distributed under the terms of the Creative Commons Attribution 4.0 International license.

\section{ABSTRACT}

Introduction: Oxidative stress is one of the inflammatory events caused by obesity. This condition is characterized by an increase in various inflammatory markers, such as intercellular adhesion molecule 1 (ICAM-1), vascular cell adhesion molecule 1 (VCAM-1), and a cluster of differentiation 40 (CD40). This study aimed to analyze the effect of Plectranthus amboinicus (Lour.) Spreng ethanol extract on ICAM-1, VCAM-1, and CD40 in obese rats. Methods: The study used a pure experimental method with a completely randomized design. There were 6 groups, namely, $\mathrm{C}-$ (negative control), $\mathrm{C}+$ (positive control), CMC (soluble control), EE300 (P. amboinicus ethanol extract, $300 \mathrm{mg} / \mathrm{kg}$ body weight [BW]), EE600 (P. amboinicus ethanol extract, $600 \mathrm{mg} / \mathrm{kg} \mathrm{BW}$ ) and EE900 groups (P. amboinicus ethanol extract, $900 \mathrm{mg} / \mathrm{kg} \mathrm{BW}$ ). Results: The results showed low levels of ICAM-1 and VCAM-1 in the blood plasma, especially in the EE900 group, but the difference was not substantial. The same trend also occurred in the expression of CD40 in the tunica intima layer of the rat aorta.

Conclusions. Thus, the administration of $900 \mathrm{mg} / \mathrm{kg} \mathrm{BW} \mathrm{P.} \mathrm{amboinicus} \mathrm{ethanol} \mathrm{extract} \mathrm{for} 45$ days has the potential to treat obesity in rats through the suppression of oxidative stress and inflammatory markers (ICAM-1, VCAM-1 and CD40)

Key words: Rats, Enzyme-linked immunosorbent assay, Immunohistochemistry, Plant extract, Obese.

\section{INTRODUCTION}

Obesity can cause various diseases, such as atherosclerosis. It has fatal effects and can even cause death if left untreated. The markers of atherosclerosis include molecule 1 VCAM-1., ICAM-1 and cluster of differentiation 40 (CD40). ${ }^{3,4}$ ICAM-1, also known as CD54, is an adhesion molecule with similar structure and function as VCAM-1. ${ }^{2-4}$ VCAM-1 concentration increases remarkably after the cytokine stimulation of endothelial cells. VCAM-1 is expressed in neurons, fibroblasts, smooth muscle cells, macrophages, and endothelial cells. ${ }^{3}$ The synthesis and secretion of ICAM-1 can be stimulated by interleukin-1 (IL-1) and tumour necrosis factor- $\alpha$ (TNF- $\alpha) .^{2-4}$ ICAM-1 serves as a ligand for lymphocyte function-associated antigen 1 (LFA-1). ${ }^{2,4,6}$ Upon activation, ICAM-1 or LFA-1 binds the leukocytes to endothelial cells, allowing the cells to migrate to the tissues

Increased ICAM-1 levels can be observed in patients with cardiovascular disease, oxidative stress and abdominal obesity. ${ }^{7}$ ICAM- 1 promotes angiogenesis and can be used as an indicator of endothelial cell activation or damage. ${ }^{78}$ Adhesion molecules mediate cell interactions with the extracellular matrix, as well as other cells. Thus, adhesion molecules and extracellular matrix molecules are used as markers of endothelial dysfunction (ED) and are involved in the pathogenesis of atherosclerosis. ${ }^{9}$ Proinflammatory cytokines lead to the increased ICAM-1 expression in the vascular endothelium and the activation of leukocyte integrins, which result in the leukocytes adhesion to endothelial cells and their migration to the sites of inflammation. ${ }^{10}$ VCAM-1 expression in small blood vessels increases after the cytokine stimulation of endothelial cells, and patients with coronary heart disease have higher levels of VCAM-1 compared with normal epicardial coronary arteries. ${ }^{2-6}$ People with higher basal levels of ICAM-1 have a double risk of developing cardiovascular disease. Thus, ICAM-1 is also a biomarker of ED. ${ }^{2-6}$ These two markers of plasma ED are closely associated with total mortality from cardiovascular disease. Both types of adhesion molecules were expressed in the aortic endothelium and in areas prone to atherosclerosis under experimental conditions. ${ }^{9}$

Plectranthus amboinicus (Lour.) Spreng. is an herb that has the therapeutic and nutritional properties of its multipurpose phytochemicals for a variety of biomedical applications. ${ }^{11}$ The essential oil of this herb has significant antioxidant properties against the stress-causing factors of lung cancer, Cardiovascular Disorders, Analgesic Activity, Activity against Genitourinary Diseases, Anti-Inflammatory Activities and Antitumorigenic Activities. ${ }^{11-14}$ This study aimed to analyse the effect of Plectranthus amboinicus (Lour.) Spreng ethanol extract on ICAM1 , VCAM- 1 and CD40 in obese rats. 


\section{MATERIALS AND METHODS}

\section{Ethanol extract of $P$. amboinicus (Lour.) Spreng}

The extract was made at the Pharmacy Laboratory of the University of Sumatera Utara, P. amboinicus (Lour.) leaves were collected, cleaned of dirt and dried in an oven at $40{ }^{\circ} \mathrm{C}$. About $1000 \mathrm{~g}$ of dried leaves was mashed in a blender. The drying process is carried out based on drying andaliman (Zanthoxylum acanthopodium), so that the phytochemical content and bioactive compounds in the plant are not lost due to heat. ${ }^{15}$ ${ }^{18}$ The simplicia powder formed was placed in a macerator with 10.000 $\mathrm{mL}$ of $70 \%$ ethanol for 6 hours. The mixture was stirred occasionally for up to 18 hours. The leaf powder was separated using Whatman paper. Then, $5000 \mathrm{~mL}$ of $70 \%$ ethanol was added again (half of the previous volume). The meserate was separated after 18 hours by filtering it with Whatman paper, and the extract was concentrated at $30-50{ }^{\circ} \mathrm{C}$ in a rotary evaporator. A water bath with a temperature of $\pm 40^{\circ} \mathrm{C}$ was used to remove water from the extract and obtain a constant weight. The process of making this extract is based on the research method by Ilyas. ${ }^{19,20}$

\section{Animal handling}

Twenty-four male Wistar rats (Rattus norvegicus L.) were obtained from the animal pen of the Biology Department, Faculty of Mathematics and Natural Sciences, Universitas Sumatera Utara, Medan, Indonesia. Rats aged 8-11 months and weighed 180-200 g were given a standard diet of CP511 with the addition of a high-fat diet, which comprised $10 \%$ goat fat, $1 \%$ cholesterol, $0.2 \%$ cholic acid, $10 \%$ quail egg yolk and standard feed, for 21 weeks. The rats were housed in a $30 \times 15 \times 40 \mathrm{~cm}^{3}$ cage, which was covered with husks and cleaned every day.

\section{Research design}

Each treatment group consisted of six Wistar rats with four replications and was given tap water ad libitum and food for 45 days. There are six groups: the negative control group (C-), positive control group $(\mathrm{C}+)$, CMC group, and three groups of $P$. amboinicus (Lour.) Spreng extract $(300 \mathrm{mg} / \mathrm{kg} \mathrm{BW}=\mathrm{EE} 300,600 \mathrm{mg} / \mathrm{kg} \mathrm{BW}=\mathrm{EE} 600$ and $900 \mathrm{mg} / \mathrm{kg}$ $\mathrm{BW}=\mathrm{EE900)}$. The treatments were administered daily using an oral swab. Group C+ was given cholesterol feed, the CMC group was given cholesterol feed and CMC, EE300 was given cholesterol feed and 300 $\mathrm{mg} / \mathrm{kg}$ BW of $P$. amboinicus ethanol extract for 45 days, EE600 was given cholesterol and $600 \mathrm{mg} / \mathrm{kg} \mathrm{BW}$ of $P$. amboinicus for 45 days, and EE900 was given cholesterol feed and $900 \mathrm{mg} / \mathrm{kg}$ BW of $P$. amboinicus for 45 days. This study was approved by the animal health research ethics committee (No. 0492, KEPH-FMIPA, 2018).

\section{ICAM-1 and VCAM-1 measurement}

ICAM-1 and VCAM-1 contents were analysed using enzymelinked immunosorbent assay (ELISA) kits (R\&D Systems Company, Minneapolis, USA). The final absorption was assessed with an ELISA photometer (Bio-Rad; Model 680). ${ }^{2-4,15}$

\section{Immunohistochemistry of the aorta}

The ten percent formalin is used to fix the aortic tissue at room temperature, embedded in paraffin, sliced, attached to a glass object and stained with hematoxylin-eosin. A paraffin block containing $4 \mu \mathrm{m}$ thick tissue was cut for immunohistochemistry. Antigen retrieval was performed by microwave oven heating at $800 \mathrm{~W}$ for $20 \mathrm{~min}$ in $0.1 \mathrm{M}$ citrate buffer ( $\mathrm{pH}$ 6.0) for monoclonal antibody CD40 (HM40-3) at a dilution of 1:100. The detection of these CD40 was a two-stage polymerbased technique (Envision K-5007, Dako Corp., Glostrup, Denmark). Tracking dye was Diaminobenzidine, and Harris hematoxylin was the counterstain. Tris-buffered saline substituted the primary antibodies in the control groups. CD40 was noticed in the tunica intima layer.
CD40 expression was evaluated on a semiquantitative scale of $0-3$ (negative $=0$; weak intensity staining $=1$; medium intensity staining $=2$; and strong intensity staining $=3$ ). Two pathologists were undertaken 'single blind' and independently. Inter-observer variable was $<5 \%{ }^{21}$. In cases of disagreement, the slides were re-evaluated jointly until a consensus was reached.

\section{Data analysis}

Numerical data (ICAM-1 and sVCAM-1) were tested for normal distribution and homogeneity. Data that were normally distributed and homogeneous were subjected to 'one-way ANOVA' $(\mathrm{p}<0.05)$ and post hoc test (Duncan) to compare between treatments Meanwhile, ordinal data (CD40 expression) were analysed using the Kruskal-Wallis test.

\section{RESULTS}

\section{ICAM-1 expression}

Analysis of the ICAM-1 protein expression using enzyme-linked immunosorbent assay (ELISA) showed significant results. ICAM-1 expression in the blood serum of obese rats is illustrated in Figure 1 ( $\mathrm{p}<0.05)$. The increasing doses of $P$. amboinicus extract decreased the ICAM-1 levels but not remarkably. A decrease in ICAM-1 indicates a reduced risk of atherosclerosis in the cardiac aorta. ICAM-1 mediates the binding of leukocytes with vascular endothelial cells. Thus, ICAM-1 levels help determine the thickening of the blood vessel walls.

\section{VCAM-1 expression}

VCAM-1 expression in the blood serum of high-fat diet rats is illustrated in Figure $2(\mathrm{p}<0.05)$. VCAM-1 expression decreased with increasing doses of P. amboinicus ethanol extract (EE300, EE600 and EE900). Thus, P. amboinicus ethanol extract, which also contains flavonoids, can suppress VCAM-1 expression in rat blood serum. The effect of the ethanol extract of P. amboinicus on VCAM-1 expression was more expressed than that of the $\mathrm{C}+$ group. Differences were observed in VCAM-1 expression between the group receiving P. amboinicus extract and the control group.

\section{CD40 detection}

The results of detection of CD40 expression in the aortic intima tunica of obese rats given several treatments $(p<0.05)$. The administration of ethanol extract of P. amboinicus (Lour.) Spreng at different doses did not have a substantial effect in reducing CD40 expression in obese rats. However, increasing the dose of $\mathrm{P}$. amboinicus extract showed a tendency to decrease CD40 expression in the tunica intima (Figures 3,4 and Table 1). The results of this study indicate that the phytochemical content of this plant functions as an anti-inflammatory agent to reduce CD40 expression which functions as an inflammatory mediator P.amboinicus.

\section{DISCUSSION}

In the membrane of leukocytes and endothelial cells, ICAM-1 is continuously present in low concentrations, and its concentration is greatly increased by cytokine stimulation. ICAM-1 can be stimulated by IL- 1 and TNF- $\alpha$ and is expressed in the vascular endothelium, macrophages and lymphocytes., ${ }^{2,47}$ ICAM-1 is a ligand for the leukocyte receptor, LFA-1 (integrin). ${ }^{10}$ Through ICAM-1, activated leukocyte cells bind to endothelial cells, then migrate to the endothelial tissue (aorta). ${ }^{1,27}$ Development of atherosclerosis correlate with inflammatory process. Hypercholesterolemia is one of the main risk factors for atherosclerosis. ${ }^{9}$ The water extract of Piper sarmentosum, which contains flavonoids, plays a role in reducing inflammatory markers, such as VCAM-1,ICAM-1 and C-reactive protein. ${ }^{22-24}$ 


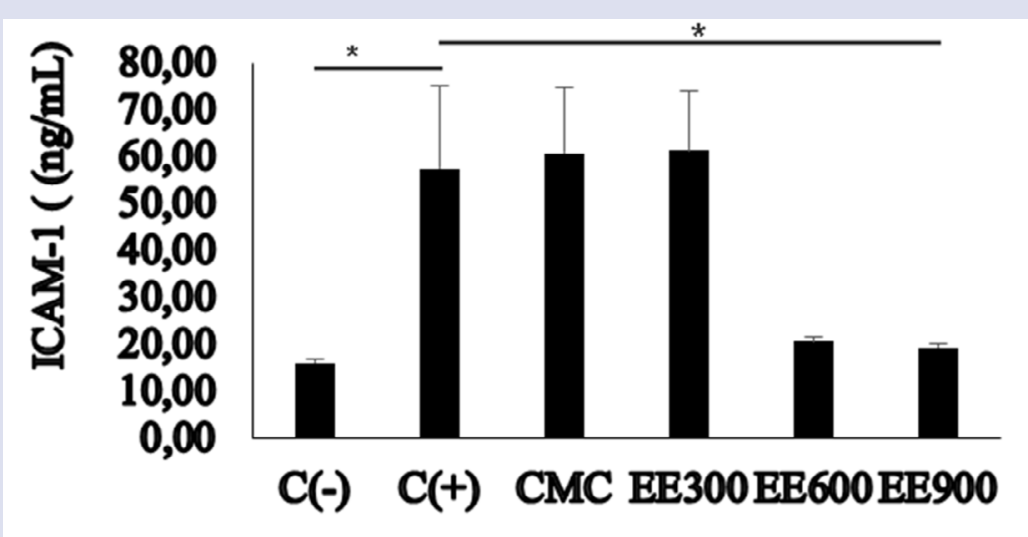

\section{Treatments}

Figure 1: Average ICAM-1 levels after the administration of $P$. amboinicus (Lour.) Spreng ethanol extract in obese rats. Note: $C_{-}$(negative control), $\mathrm{C}+$ (positive control), CMC (soluble control), EE300 (P. amboinicus ethanol extract, $300 \mathrm{mg} /$ $\mathrm{kg}$ body weight [BW]), EE600 (P. amboinicus ethanol extract, $600 \mathrm{mg} / \mathrm{kg} \mathrm{BW}$ ) and EE900 groups (P. amboinicus ethanol extract, $900 \mathrm{mg} / \mathrm{kg} \mathrm{BW}$ ). ${ }^{*} \mathrm{P}<0.05$.

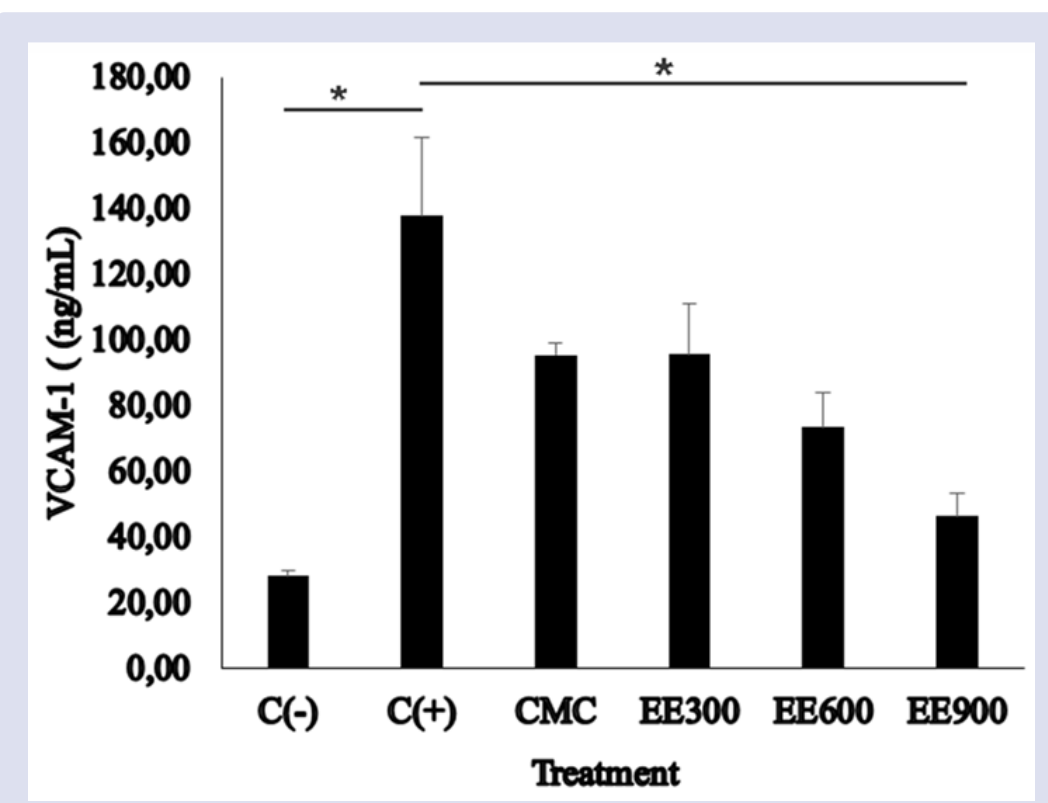

Figure 2: Average VCAM-1 level after the administration of $P$. amboinicus (Lour.) Spreng ethanol extract in obese rats. Note: $\mathrm{C}-$ (negative control), $\mathrm{C}+$ (positive control), CMC (soluble control), EE300 (P. amboinicus ethanol extract, $300 \mathrm{mg} / \mathrm{kg}$ body weight [BW]), EE600 (P. amboinicus ethanol extract, $600 \mathrm{mg} / \mathrm{kg} \mathrm{BW}$ ) and EE900 groups (P. amboinicus ethanol extract, $900 \mathrm{mg} / \mathrm{kg} \mathrm{BW}$ ).

Table 1: Descriptive data of CD40 expression in the aortic intima tunica of obese rats.

\begin{tabular}{ccccccccc}
\hline Item & Mean & SD & SE & Min. & Max. & Median & \multicolumn{2}{c}{$95 \%$ Confidence Interval for Mean } \\
& & & & & & & Lower Bound & Upper Bound \\
\hline C- & 3.00 & 3.46 & 1.73 & 0.00 & 6.00 & 3.00 & -2.51 & 8.51 \\
C+ & 7.00 & 0.82 & 0.41 & 6.00 & 8.00 & 7.00 & 5.70 & 8.30 \\
CMC & 6.75 & 0.96 & 0.48 & 6.00 & 8.00 & 6.50 & 5.23 & 8.27 \\
EE300 & 5.00 & 3.37 & 1.68 & 0.00 & 7.00 & 6.50 & -0.36 & 10.36 \\
EE600 & 5.00 & 3.37 & 1.68 & 0.00 & 7.00 & 6.50 & -0.36 & $0.13=\mathrm{p}>0.05$ \\
EE900 & 4.25 & 2.87 & 1.42 & 0.00 & 6.00 & 5.50 & -0.32 & 8.36 \\
\hline
\end{tabular}

Note: C- (negative control), C+ (positive control), CMC (soluble control), EE300 (P. amboinicus ethanol extract, $300 \mathrm{mg} / \mathrm{kg}$ body weight [BW]), EE600 (P. amboinicus ethanol extract, $600 \mathrm{mg} / \mathrm{kg} \mathrm{BW}$ ) and EE900 groups (P. amboinicus ethanol extract, $900 \mathrm{mg} / \mathrm{kg} \mathrm{BW}$ ). 




Figure 3: $C D 40$ expression in the aortic intima tunica of obese rats after different treatments. C- (negative control), $C+$ (positive control), CMC (soluble control), EE300 (P. amboinicus ethanol extract, $300 \mathrm{mg} / \mathrm{kg}$ body weight [BW]), EE600 (P. amboinicus ethanol extract, $600 \mathrm{mg} / \mathrm{kg} \mathrm{BW}$ ) and EE900 groups $(P$. amboinicus ethanol extract, $900 \mathrm{mg} / \mathrm{kg} \mathrm{BW}$ ).

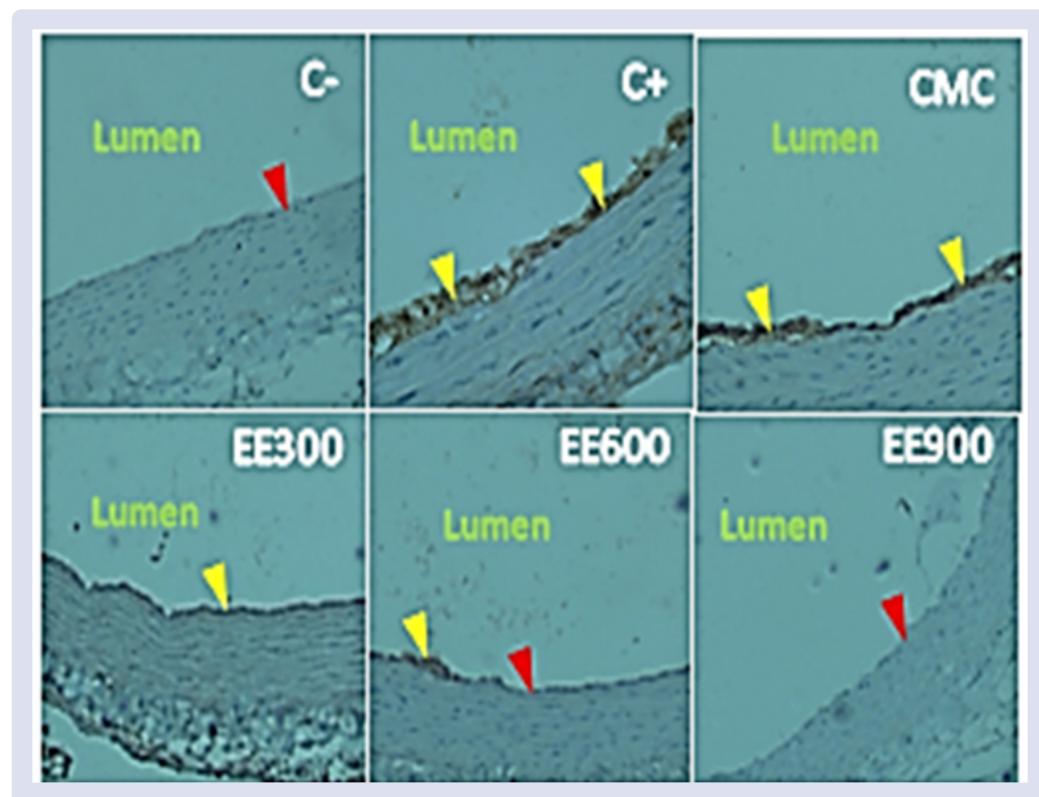

Figure 4: CD40 immunohistochemistry results in the aortic intima of obese rats. The tunica intima with CD40 is shown in yellow, and the red arrows are those without CD40. Note: C- (negative control), C+ (positive control), CMC (soluble control), EE300 (P. amboinicus ethanol extract, $300 \mathrm{mg} / \mathrm{kg}$ body weight [BW]), EE600 (P. amboinicus ethanol extract, $600 \mathrm{mg} / \mathrm{kg} \mathrm{BW}$ ) and EE900 groups (P. amboinicus ethanol extract, 900 $\mathrm{mg} / \mathrm{kg} \mathrm{BW}$ ).

VCAM-1 expression decreased with increasing doses of $P$. amboinicus ethanol extract (EE300, EE600 and EE900). Thus, P. amboinicus ethanol extract, which also contains flavonoids, can suppress VCAM1 expression in rat blood serum. Flavonoids reduce the expression of VCAM-1. ${ }^{11}$ A decrease in VCAM-1 also occurs in the intake of citrus, which contains flavonoids and thus can protect the cardiovascular system. ${ }^{25}$ Flavonoids work as antioxidants and anti-inflammatory agents and play a role in the process of regulating monocyte adhesion in cultured human endothelial cells, such as suppressing the expression of VCAM-1 and ICAM-1. The suppression of VCAM-1 and ICAM-
1 is carried out by flavonoids through the inhibition of IL- $1 \beta \cdot^{2-4,11}$ Suppressing VCAM-1 expression can reduce the binding between monocytes and $\mathrm{T}$ lymphocytes and therefore reduce the possibility of the binding of leukocytes and endothelial cells. This bond makes way for the emergence of reactive oxygen species or free radicals from oxygen, which eventually give rise to cytotoxic oxidants and inflammatory mediators that activate the complement system.

Leukocytes move freely along the endothelium under normal conditions. During ischemia and inflammation, endothelial cells 
release various mediators that cause leukocyte adhesion molecules to appear on the surface to mobilise and stimulate the leukocyte granules. The oxidants produced will cause injury to the surface of the tissue. ${ }^{2,25,26}$

The highest CD40 expression in the intima tunica was found in the $\mathrm{C}+$ group and was not remarkably different from that of the CMC group. This result is due to the fact that obesity caused by hyperlipidaemia increases lipid peroxidation, which degrades fat and produces malondialdehyde (MDA). MDA stimulates TNF- $\alpha$ and increases the incidence of oxidative stress. The increase in oxidative stress triggers the oxidation of low-density lipoprotein (LDL) and results in the adhesion of monocytes to the endothelium. These monocytes eventually turn into macrophages. Oxidised LDL is phagocytosed by the macrophages and accumulates in the endothelium to form foam cells. Finally, the inflammatory mediators CD40 and TNF- $\alpha$ expressed in muscle cells form unstable atherosclerotic plaques (rich in macrophages and foam cells. $^{2}$

The administration of different doses of $P$. amboinicus (Lour.) Spreng ethanol extract did not seem to have a subtantial effect on decreasing the CD40 expression of obese rats. However, increasing the dose of $P$. amboinicus extract showed a tendency to decrease CD40 expression in the tunica intima (Figure 4). This result shows that the phytochemical content of these plants, such as flavonoids, can function as an antiinflammatory agent to decrease the expression of CD40, which functions as an inflammatory mediator., $P$. amboinicus contains several phytochemical classes, including diterpenoids, monoterepenoids, triterpenoids, phenolics, sesquiterpenoids, flavonoids and esters. ${ }^{11-14}$

New insights into the functions and mechanisms of $P$. amboinicus include the following: its anti-inflammatory ability reduces swelling (oedema) in carrageenan-induced rat and the levels of proinflammatory mediators (TNF- $\alpha$ and COX-2), ${ }^{2,11,27}$, its antioxidant ability is indicated by increased levels of superoxide dismutase, ${ }^{27-29}$ and glutathione reductase and decreased levels of MDA and glutathione peroxidase, as well as indomethacin (a drug used to treat the symptoms of swelling and joint pain in osteoarthritis or rheumatoid arthritis). ${ }^{27-30}$

\section{CONCLUSION}

The administration of $900 \mathrm{mg} / \mathrm{kg}$ BW P. amboinicus ethanol extract for 45 days has the potential to treat obesity in rats through the suppression of oxidative stress and inflammatory markers (ICAM-1, VCAM- 1 and CD40).

\section{REFERENCES}

1. Rasmuson J. Neutrophil-Induced Endothelial Barrier Dysfunction In Acute Inflammation - Mechanisms And Therapeutic Strategies. Thesis, Karolinska Institutet. Stockholm, 2020

2. Yang $L$, Froio RM, Sciuto TE, Dvorak AM, Alon R, Luscinskas FW. ICAM-1 regulates neutrophil adhesion and transcellular migration of TNF- $\alpha$ activated vascular endothelium under flow. Blood. 2015;106(2):584-93.

3. Krzesz R, Wagner AH, Cattaruzza M, Hecker M. Cytokine-inducible CD40 gene expression in vascular smooth muscle cells is mediated by nuclear factor $\kappa \mathrm{B}$ and signal transducer and activato of transcription-1. FEBS Letters. 1999;453(12):191-6.

4. Reina M, Espel E. Role of LFA-1 and ICAM-1. Cancers. 2017;9(11):153.

5. Littler AJ, Buckley CD, Wordsworth P, Collins I, Martinson J, Simmons DL. A distinct profile of six soluble adhesion molecules (ICAM-1, ICAM3, VCAM-1, E-selectin, L-selectin and P-selectin) in rheumatoid arthritis. Rheumatology. 1997;36:164-9.

6. Jantan I, Ahmad W, Bukhari SNA. Plant-derived immunomodulators: An insight on their preclinical evaluation and clinical trials. Front Plant Sci. 2015;6(AUG):118.

7. Tong F, Liu S, Yan B, Li X, Ruan S, Yang S. Quercetin nanoparticle complex attenuated diabetic nephropathy via regulating the expression level of ICAM-1 on endothelium. Int J Nanomedicine. 2017:12:7799-813.

8. Li J, Tan M, Xiang Q, Zhou Z, Yan H. Thrombin-activated platelet-derived exosomes regulate endothelial cell expression of ICAM-1 via microRNA-223 during the thrombosis-inflammation response. Thrombosis Research. 2017; 154:96-105.
9. Zhao J, Chen H, Liu N, Chen J,Gu Y,Chen J, Yang K. Role of Hyperhomocysteinemia and Hyperuricemia in Pathogenesis of Atherosclerosis. J Stroke and Cerebrovascular Diseases. 2017;26(12):2695-9.

10. Pflugfelder SC, Stern M, Zhang S, Shojaei A. LFA-1/ICAM-1 Interaction as a Therapeutic Target in Dry Eye Disease. J Ocular Pharmacology and Therapeutics. 2017;33(1):5-12.

11. Arumugam G, Swamy M, Sinniah U. Plectranthus amboinicus (Lour.) Spreng Botanical, Phytochemical, Pharmacological and Nutritional Significance. Molecules. 2016; 21(4):369

12. Manjamalai A, Grace DVB. Volatile constituents and antioxidant property of essential oil from Plectranthus amboinicus (Lour). Int J Pharm Biol Sci. 2012;3:445-58.

13. Morton JF. Country borage (Coleus amboinicus Lour.): A potent flavoring and medicinal plant. J. Herbs Spices Med. Plants 1992; 1;77-90. https://doi. org/10.1300/J044v01n01_09

14. Ramalakshmi P, Subramanian N, Saravanan R, Mohanakrishnan H, Muthu M Anticancer effect of Coleus amboinicus (Karpooravalli) on human lung cancer cell line (A549). Int J Dev Res. 2014;4;2442-9.

15. Situmorang PC, Ilyas S, Hutahaean S. Study of Combination of Nanoherbal Andaliman (Zanthoxylum acanthopodium) and Extra Virgin Olive Oi (EVOO) Effects in the Expression of Malondialdehyde (MDA), Heat Shock Protein-70 (HSP70) and Placental Histology of Preeclamptic Rats. Pharm Sci. 2019;25(3):205-20.

16. Situmorang PC, Ilyas S, Hutahaean S. Effect of Combination of Nano Herbal Andaliman (Zanthoxylum acanthopodium DC.) and Extra Virgin Olive Oil (EVOO) to Kidney Histology of Preeclampsia Rats. IOP Conf. Series: Earth and Environmental Science. 2019;305(2019)01208.

17. Situmorang PC, Ilyas S, Hutahaean S, Rosidah R, Manurung RD. Acute toxicity Test and Histological Description of Organs after Giving Nano Herbal Andaliman (Zanthoxylum acanthopodium). Rasayan J Chem. 2020;13(2):780-8.

18. Situmorang PC, Ilyas S, Hutahaean S, Rosidah. Effect of Nanoherbal Andaliman (Zanthoxylum acanthopodium) and Extra Virgin Olive Oil Combination on Preeclamptic Rats Liver Histology. Open Access Maced J Med Sci. 2019;7(14):2226-31.

19. Ilyas $\mathrm{S}$. Histological changes in the testis if the guinea pig during administration of methanol extract of bitter melon (Momordica charantia L.) seed and DMPA. J Phys Conf Ser. 2018;1116(5).

20. llyas S. Effect of methanolic Momordica charantia seed extract and depot medroxyprogesterone acetate (DMPA) to quantity and quality of rat sperm. Int J PharmTech Res. 2014;6(6).

21. Ilyas $\mathrm{S}$, Hutahaean $\mathrm{S}$, Nursal. Apoptosis overview of cerebellum Purkinje cell in mice (Mus musculus L.) after exposure to methanol extract of the seeds of bitter melon (Momordica charantia) and DMPA. Int J PharmTech Res. 2016;9(9)

22. Chiu YJ, Huang TH, Chiu CS, Lu TC, Chen YW, Peng WH, et al. Analgesic and antiinflammatory activities of the aqueous extract from Plectranthus amboinicus (Lour.) Spreng. both in vitro and in vivo. Evidence-based Complement Altern Med. 2012;508137.

23. Cheng K-Y, Lin Z-H, Cheng Y-P, Chiu H-Y, Yeh N-L, Wu T-K, et al. Wound Healing in Streptozotocin-Induced Diabetic Rats Using Atmospheric-Pressure Argon Plasma Jet. Sci Rep. 2018;8(1):12214.

24. Chang CLT, Lin Y, Bartolome AP, Chen Y, Chiu S, Yang W. Herbal Therapies for Type 2 Diabetes Mellitus: Chemistry, Biology, and Potential Application of Selected Plants and Compounds. 2013;378657.

25. Fuior EV, Deleanu M, Constantinescu CA, Rebleanu D, Voicu G, Simionescu $\mathrm{M}$, et al. Functional Role of VCAM-1 Targeted Flavonoid-Loaded Lipid Nanoemulsions in Reducing Endothelium Inflammation. 2019;11(8):391.

26. Zhao Y, Song J, Bi X, Gao J, Shen Z, Zhu J, et al. Thymosin B4 promotes endothelial progenitor cell angiogenesis via a vascular endothelial growth factor-dependent mechanism. Mol Med Rep. 2018;18;2:2314-20.

27. Grayer RJ, Eckert MR, ever A, Veitch NC, Kite GC, Paton AJ. Distribution of exudate flavonoids in the genus Plectranthus. Biochem Syst Ecol. 2010;38:33541.

28. Yusuf F, Ilyas S, Damanik HA, Fatchiyah F. Microbiota Composition, HSP70 and Caspase-3 Expression as Marker for Colorectal Cancer Patients in Aceh, Indonesia. Acta Med Indones. 2016;48(4).

29. Oliveira JS, Silva AAN, Junior VAS. Phytotherapy in reducing glycemic index and testicular oxidative stress resulting from induced diabetes: a review. Braz J Biol. 2017;77(1):1-11.

30. Swamy MK, Arumugam G, Kaur R, Ghasemzadeh, A, Yusoff MM, Sinniah, UR GC-MS Based Metabolite Profiling, Antioxidant and Antimicrobial Properties of Different Solvent Extracts of Malaysian Plectranthus amboinicus Leaves. Evidence-Based Complementary and Alternative Medicine. 2017:1-10. 


\section{GRAPHICAL ABSTRACT}

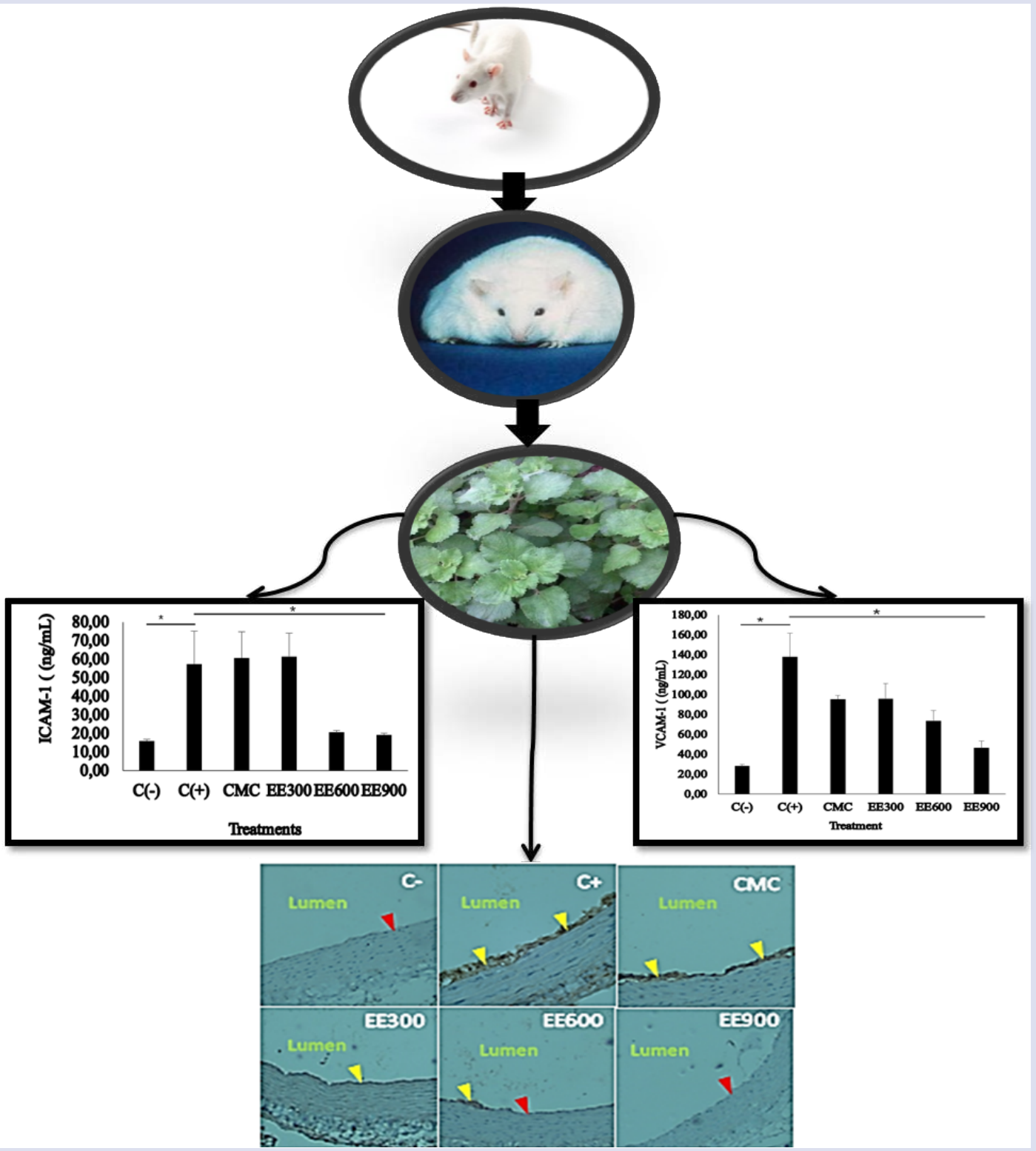

\section{ABOUT AUTHORS}

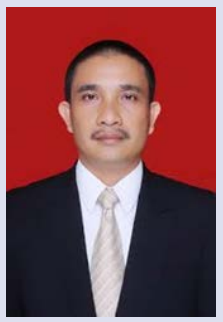

Karnirius Harefa, He is the first author in this research. He designed this research, analyzed the data and prepared the articles. He is also a Lecturer at Sari Mutiara Indonesia University, Medan.



Prof. Dr. dr. Delmi Sulastri, MS, SpGK, She is a doctor and also permanent Lecturer at the Faculty of Medicine, Public Health Doctoral Study Program, Andalas University, Padang, Subject: Nutrition, Public Health. 


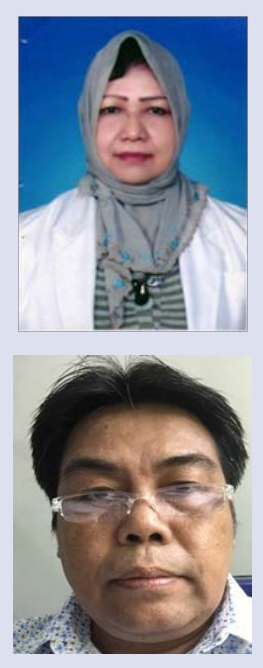

Prof.Dr.dr. Ellyza Nasrul, Sp.PK(K), She is a doctor and also Professor at the Doctoral Program in Biomedical Sciences, Faculty of Medicine, Andalas University, Padang. Indonesia.

Prof.Dr.Drs. Syafruddin Ilyas, M.Biomed. Professor in Biology, Faculty of Mathematics and Natural Sciences, University of Sumatera, Medan. Indonesia.

Cite this article: Harefa K, Sulastri D, Nasrul E, Ilyas S. Analysis of Several Inflammatory Markers Expression in Obese Rats given Plectranthus amboinicus (Lour.) Spreng Ethanol Extract. Pharmacog J. 2021;13(1): 172-8. 